\title{
Pearl Jephcott: The Legacy of a Forgotten Sociological Research Pioneer
}

\author{
John Goodwin and Henrietta O'Connor
}

\begin{abstract}
While the lives and works of many sociologists have now been well documented numerous sociologists at the 'coal face' of social research remain ignored. As such, beyond the contributions of those more 'well known' scholars, considerably more needs to be done to examine the history of our discipline and reassess the significant contributions made by 'other' researchers so that we may reappraise what can be learnt from these 'pioneer scholars'. In this paper we focus on Pearl Jephcott (1900-1980) who in a research career spanning forty years, but now largely forgotten, was at the forefront of methodological innovation in the 1960s. We offer an introduction to her work focusing on questions such as why were her methods innovative and why is she now ignored within sociology?
\end{abstract}

Keywords: $\quad$ History of Sociology, Pearl Jephcott, Research Methods, Innovative Methods, Women Sociologists

\section{Contact details}

John Goodwin (corresponding author)

Room 617 Ken Edwards Building

University of Leicester

University Road, Leicester, LE1 7RH

Tel: 01162525944

e-mail: jdg3@leicester.ac.uk

Henrietta O'Connor

Room 615 Ken Edwards Building

University of Leicester

University Road, Leicester, LE1 7RH

Tel: 01162525944

e-mail: hso1@leicester.ac.uk 


\section{Introduction}

The lives and works of many sociologists have now been well documented and explored (see, for example, Horowitz 1983; Johnston 1995; Chriss 2001; Gerhardt 2002; Stanley et al 2010, Oakley 2011; Aronowitz 2012; Lybeck 2013), yet there are numerous others who have made, or continue to make, an outstanding contribution to the understanding of social life but have become lost within the minutia of academic historiographies. This may be due to the fact that, in the main, most academic biographies tend to focus on the 'established' or 'establishment' figures associated with a particular theory, a particular school of thought, they are holders of key disciplinary posts or they are those who have become/became public intellectuals and, therefore, had a profile within the wider consciousness beyond academia. However, as suggested elsewhere, even when these biographical accounts are combined with boarder authoritative accounts of the discipline (see, for example Platt 2003; Halsey 2004) this ' ...standard history is by no means a fully complete nor an uncontentious one' (Goodwin and Hughes 2011: 678). These accounts are partial and ignore the many (see, for example, Savage 2008). For the numerous sociologists at the 'coal face' of social research - be it those collecting data, those undertaking fieldwork or, more recently, those dedicated to a career of contract research combined with some teaching, the grand intellectual biography is not to be theirs. Yet to ignore the contributions of these 'outsiders' means a full understanding of the sociogenesis of the discipline will never be complete (see Elias 2009). As such, beyond the contributions of those more 'well known' scholars, considerably more needs to be done to examine the history of our discipline and to reassess the significant contributions made by 'other' researchers, perhaps earlier unsung forerunners of theory, method and sociological practice, in order that we may better understand the histories our discipline and that we may also reappraise what can be learnt from these 'pioneer scholars'. We are pressured to seek out the 'new' without always fully understanding the value of our past.

Pearl Jephcott (1900-1980) is perhaps one such researcher whose contribution to sociology, and the sociologies of gender, class, youth and community in particular, is suitable for reassessment. This is, not least, because there is a breadth and depth to her research contribution that rivals that of many established scholars. In a research career spanning some forty years, this now largely forgotten researcher produced eight major books on everything from girls' lives, leisure, inner city violence and urban decay, the 
experiences of women workers through to the quotidian realities of high-rise living. Her books include: Girls Growing Up (1942), Rising Twenty (1948) Some Young People (1954) Married Women Working (1962), A Troubled Area: Notes on Notting Hill (1964), Time of One's Own (1967) and Homes in High Flats (1971). Alongside the books were numerous reports and articles on delinquency, urban life and so forth in places such as Glasgow, London, Birmingham and Hong Kong. Many of these books and reports have paved the way for numerous of the subsequent developments that were to come in the sociology of gender, urban sociology and the sociology of youth. Jephcott's contribution is clear as, for example, Banton (1964) has argued research with 'recognizably anthropological character' was central to transformation of sociological research from the 1940s onwards. He wrote:

I would go so far as to suggest that the studies of Pearl Jephcott...and other investigators of this time also had an anthropological tone. They brought back reports to the educated public as from another country, quoting the words and describing the actions of the strange inhabitants. Above all, they let their subjects speak for themselves instead of pressing their stories into the mould of middle-class judgement. Sociologists had been discouraged from studying such groups by a paradigm that told them their subject should be a sort of history with the dates left out. (Banton 1964:103)

Alternatively as Oakley (1989) notes, that the tendency to locate women's studies, and the influence of feminism on the social science research agenda as only beginning in the 1960s, is to:

...devalue some significant earlier contributions, including such classics as Myrdal and Klein's Women's Two Roles (1954), Klein's earlier The Feminine Character (1949) and work done by social researchers such as Pearl Jephcott (1949 and 1962) who studied working-class women at a time when the study of working-class culture meant studying men. (Oakley 1989: 445)

Following the lead of Oakley (1989) and Banton (1964) combined more broadly with the established critical accounts of the contribution of women to British sociology (see, for example Roberts and Woodward 1981; Platt 2004, 2007) we would argue Pearl Jephcott deserves far more attention than she received in her lifetime. In this paper we aim to 
reintroduce Pearl Jepchott's work by focusing on a number of specific questions, including why were her methods innovative and why is she now ignored within sociology? In the next section we begin by briefly outlining the location of the source material for our research before moving on to how we came to be interested in Jepchott's work, our encounters with her research and by offering a short account of Jephcott's background. We then go on to consider her major works, exploring the most striking features of her sociological practice.

\section{(Re)Locating Pearl Jephcott: Our 'Encounters' with Her Legacy}

One of the main difficulties anyone one interested in the history of sociology encounters is locating useful and useable source materials. This is especially hard when the research focuses on someone other than established figures who were firmly located within the discipline as well as having well recognized institutional links. As suggested above, for those at the 'coal face' of social research it may be harder to locate materials relating to their contribution given a wide variety of factors such as frequency of job moves and a lack of recognition of the value of archiving or retaining materials relating to their contribution. In the case of Pearl Jephcott, we would suggest she has a real legacy within British sociology, save for tantalising references to her in the works of Banton (1964) and Oakley (1989), a brief biographical account by Smith (2008) and a concise citation in the Oxford Dictionary of National Biography (Turnbull 2004), she is now difficult to 'locate'. There are very few currently who know of her work or why her research was/is so important. Like Elizabeth Bott, Jephcott has become 'one of the most strangely neglected, figures in the history of post-war British social science' (Savage 2008: 579). Jephcott is one of the unacknowledged early pioneers of 'good' social science research (see Hughes 2013) based on 'reality congruent' informed theory developed in order that she may cast a lens on the realities of working class life. As Turnbull (2004: 2) notes

All Jephcott's work was suffused with concern for humanity and particularly for working-class people. From her early work as a youth leader, through her various research posts, she explored their lives with enormous sympathy and no sentimentality.

Until recently we had only a vague appreciation of Jephcott's legacy and we came to her work by a very circuitous route. For the last thirteen years we have been undertaking a 
restudy of a 'lost' project on youth transitions (see Goodwin and O'Connor 2005, 2013; O'Connor and Goodwin 2012). It was during our research, across various University and National archives, that we discovered some of the same research team had also undertaken an earlier study (which also largely failed save for one publication - see Smith 1961) and that this research was direct replication of Pearl Jephcott's Married Women Working (1962). Our interest in Jephcott escalated from there. In order to 'locate' Jephcott we systematically obtained all of her published, and some unpublished works, and scoured them for relevant information - places she had worked, those who she had collaborated with, funders of her research, those who had published her work and so forth. We then contacted as many of those sources as we could, focusing on institutional archives and organisations for whom she had worked or received funding. Materials relating to Jepchott are spread far and wide, reflecting the number of locations and universities she worked in. To date we have collected material from the Norbert Elias archive in Marbach, Germany, archives at the Universities of Glasgow, Reading, York, London Metropolitan and the London School of Economics. This is supported with additional materials from other sources such as the National Archives, UNICEF, The Trust for London, Birmingham Archives and Heritage Service and the Bellahosuton Bequest Fund. Of these perhaps the most important repository of Jepchott's work is the University of Glasgow archive where an almost complete set of archive materials relating to Jephcott's study Homes in High Flats (1971) is held. However, taken together the archived material that does exist offers a significant amount of detail into Jepchott's innovative sociological practice.

\section{(Re)Introducing Pearl Jephcott ${ }^{1}$}

Pearl Jephcott trained initially as a historian, graduating from the University of Wales (Aberystwyth) with a degree in History in 1922. Although she attended a grammar school and went on to university, her family background was lacking in 'those aspects of cultural capital which are usually emphasised as vitally important for academic success' (Purvis, 2008: 364). This was perhaps the first sign that in common with other academic women of the post-war period her academic career path was to be a challenging one.

Indeed on leaving university Pearl held a variety of non-academic roles eventually becoming the national organiser for the National Association of Girls' Clubs (Turnbull, ODNB). While in this role Pearl wrote what was to become the first of a number of 
books based on her research: Girls Growing Up (1942). This was followed quickly by two further studies of the experiences of girls and young women growing up soon after the Second World War: Clubs for Girls (1943) and Rising Twenty (1948). This research resulted in her being awarded an MA by publication in 1946. She was also awarded a prestigious Barnett Fellowship which enabled her to complete Rising Twenty but we know little about this period of her life.

Jephcott went on to secure her first academic position in 1950, at the age of 50, when she accepted a research job at the University of Nottingham. During her four years at Nottingham she was involved in two research projects and published her fourth book, Some Young People (1954) on the basis of this. In 1954 Pearl moved to the LSE and here she carried out a large-scale project, directed by Richard Titmuss, on married women's employment which led to the publication of the book Married Women Working' (1962) coauthored with Nancy Seear and John Smith. Jephcott left the LSE in the early 1960s and Turnbull, who wrote Jephcott's biography in the Oxford Dictionary of National Biography, writes that she left the institution 'reluctantly'. We do not know any more about the circumstances of her departure but given that during her time at LSE Jephcott was highly productive academically, and was invited to join national committees on issues around youth, it is all the more surprising that she was not retained. After leaving the LSE she worked without an institutional home, leading a study on the Notting Hill neighbourhood of London. In the mid-1960s, by then aged in her mid-60s, Jephcott was employed at the University of Glasgow to lead a study on youth leisure in Scotland, published as Time of One's Own (1967). She went on research the implications of high-rise living, at the time a new social phenomenon in Glasgow. This study culminated in the publication of her last book, Homes in High Flats (1971). Although she continued to be research active until her death in 1980 Pearl did not work in a university again after leaving Glasgow in 1970.

\section{Jephcott's Eclectic, 'Innovative' and Extensive Research Practice}

Why is Jephcott's approach to research different or worthy or further consideration? We would like to argue that Jephcott's approach to research is worthy of revisiting for three main reasons. First, Jephcott was fundamentally concerned for the individuals who she had portrayed in her writings. Although many would claim the same of themselves, or for those they champion, this is no clichéd assertion. As Goudsblom (1977: 6-7) writes: 
Unfortunately it is not superfluous to remind ourselves that in sociology we are dealing with people. All too often sociologists....start out with an abstract conception of social action or social system.... it makes sense, therefore, to state quite explicitly that we are concerned with people, bonded together in dynamic constellations...'

The girls, the women, the young people and those living in high-rise flats are not mere 'subjects or respondents' but are people who have something to say, some insight to offer and they were people who mattered greatly to Jepchott. It is this concern for people (still often overlooked in contemporary sociology with the pressure to publish etc.) that reinforces our conviction that Jephcott is well worth revisiting. Second, and like Banton (1964), we would suggest an appealing aspect of Jephcott's approach is her 'lack of side'. Jepchott's research does not follow the 'partisan track' of beginning with an a priori conclusion, or a dominant ideological standpoint, but instead is a non-judgemental, 'nonpartisan' style of research where the researcher documents to 'explain' and offers evidence-based recommendations, or empirically grounded theory, where possible. In an era witnessing a resurgence of 'sociology of/as activism' this may not appear very radical and yet, perhaps in the 'Millsian' sense, Jephcott was engaged in a definitive 'political act' of writing to speak the politics of truth to power. The realities of lives are laid bare for all to see so as to 'raise awareness and generate concern' (DeVault 2007: 158).

Finally, and most important for our discussion here, is Jephcott's 'methodological eclecticism' in her approach to data collection and her developments and/or innovations in research design. One reading of her work could focus on the large-scale social surveys she utilised that were typical of British 'empirical' sociology of the 1940s, 1950s and 1960s (for a fuller discussion see Halsey 2004: 187-192) the heritage of which can be traced back to Booth and Beatrice and Sidney Webb in the nineteenth century (DeVault 2007: 158). Jephcott's work could be read as empiricist, it could fit into the empiricist approaches typified by the low level quantification to which Halsey (2004) refers. Yet at the same time Jephcott was not to be constrained by the large-scale survey method. She looked well 'beyond' the interview and questionnaire for the data she need to help reveal the realities and actualities of everyday life. As Turnbull (2004:1) suggests her approached 'involved detailed ethnographic research using participant observation, interviews, and autobiographical accounts, and offered practical recommendations to improve the quality of life of their subjects'. In this 
connection she drew upon a varied range of data sources and data collection methods auto/biographical accounts, images and so forth well ahead of the 'rise' in usage of such qualitative research methodologies. We also argue that she was innovative in her methodological approach. However, we are mindful of the arguments developed by Wiles et al (2011) and Nind et al (2013) in making claims of 'innovation' on behalf of Pearl Jephcott. They suggest that most research methods claimed as innovative are not innovative but are, instead, adaptations or developed applications of what has gone before. Moreover, innovation seems to reflect 'current popularity of, particular types of method and approaches, particular performative methods' (Wiles et al 2011: 600). However, Wiles et al (2011) also assert that innovation can be methods that have 'not (yet) been taken up by the wider community' (Wiles et al 2011: 588). We would suggest that it is here where Jephcott can truly be said to be innovative as she was collecting data in ways that were not popular or fashionable, but which have since become so.

\section{A Focus on the 'Quotidian': Specimen Days of Women and Children}

One of the most striking aspects of Jephcott's work is her focus on the quotidian. Her interest was in the ordinary, mundane, day-to-day lives of 'ordinary' people'. The methods she employed to research such lives closely mirror the approaches that would subsequently come to be aligned with feminist methodologies.

Delamont's (2003) account of the establishment of feminist sociology includes an exploration of feminist inspired methods of research and areas of sociological interest. It was through the advent of feminist sociology that research in 'new' sociological areas, 'the scrutiny of the private', (Delamont, 2003: 42) came to the fore encompassing previously neglected areas such as housework, caring and childbirth. Ann Oakley is widely recognised as being at the forefront of the movement towards understanding the daily domestic world of women and children. The Sociology of Housework (1974) became a classic text in part because it was widely viewed as the first major study of issues impacting on women, family and households. However, much of Jephcott's work not only pre-dates Oakley's but was concerned with broadly similar issues. Married Women Working for example, explores not only the employment experience of married women but also the women's daily strategies for carrying out household tasks and managing childcare. As Jephcott (1962: 26) notes in the opening chapter to this book 
'...the wife who works plays so many roles in our social structure She is a citizen, a consumer, an employee, a wage earner, a member of a working group, a wife, probably a mother - not to mention a person in her own right'.

Jephcott's emphasis on the importance of the everyday lives precedes by some time the later interest from feminist sociologists who succeeded in mainstreaming these aspects of daily life as a legitimate concern for sociologists.

Not only was Jephcott's research concerned with aspects of society that would later become key concerns for feminist sociologists she was also a pioneer in the use of methods which we would now view as feminist approaches to data collection. Such methods included activity diaries, focus groups with young mothers, child-centred data collection and visual methods. For example, daily activity diaries of women who took part in the Married Women Working project were collected to show how the women structured their day. These accounts focused on mundane housework: shopping, cleaning, laundry and childcare and reflect the type of data collected by Oakley in the 1970s. More unusually, the children were asked to complete diaries showing how they used their leisure time, for example "5.15pm Came in for television. Saw Buffalo Bill; 5.45pm Took my dog for a walk; 6.00pm Played on my skates' (Jephcott 1962: 153).

This emphasis on children was also apparent in the Homes in High Flats study. Mothers were asked to provide written accounts of their daily life since moving in to the high-rise building and focus groups (though not termed as such at the time) were conducted with the mothers of pre-school children on the estates. These groups 'were kept informal and the mothers appeared to have so many pressing difficulties that they talked readily' (p.32). Jephcott recognised that the children themselves would have opinions on their living environments and schoolchildren were invited to participate in the research by writing and drawing pictures of life in a high-rise home: 'even when no great shakes at writing they had definite ideas on what makes a good place to play' (p.81). Where children's responses are used in the final publication their written words are reproduced exactly as they wrote them: I would like to play with people that are frendlay and dont fight with each other and dont talk scrufy I lik places that are tiddy and not all papers about...(p.85)' suggesting that Jephcott was very concerned about preserving and presenting the authentic voices of her participants, again a very unusual method for the period. 
A final example here of Jephcott's interest in the daily life of individuals can be found in her study of young people's leisure time in Scotland, Time of One's Own (1967). The methodological approach had four distinct strands: interviewing, focus groups, written material (including diaries and drawings) and a longitudinal study of a selected group of young people. The scale of the undertaking is phenomenal - some 76 focus groups were held and the researchers collected written material from some 1600 adolescents alongside drawings that illustrated participants' views on leisure. Local artists were also commissioned to create images of neighbourhood scenes 'on the assumption that the artist has a clearer insight than the ordinary person' (p.44). The final strand of this project was a longitudinal element which aimed to follow the progress of a group of school leavers. It is not clear how successful this strategy was, however, what this does illustrate is the extraordinarily ambitious scope of the project.

Thanks to the comprehensiveness of Jephcott's publications it is relatively easy to discover how she approached each research project. Each publication includes a very detailed methods chapter, usually a candid explanation of the evolution of the research project at a time when it was more common to present research as a straightforward, orderly process. Jephcott's account in 'Time of One's Own', and in her other publications, is honest and open. She describes mild disagreements amongst the team, candid responses from participants ('I think what you are doing is a waste of time' (Jephcott, 1967: 42), fieldwork approaches that were unsuccessful and difficult research encounters in the field: 'the family's two year old sidled up to the interviewer with the engaging information that he was about to pee' (p.38). Other published work of the period and indeed contemporary publications, tend to sanitise the research process and historically there has been a 'considerable divergence between how sociological research has actually been done and what is found in textbooks' (Bell and Newby, 1976:9). Jephcott's retelling of the research process described sociological research 'how research is actually done' (Bell and Newby, 1976: 10). That Bell and Newby (1976:9) were aiming to compile a collection of such accounts in the 1970s reveals how unusual and novel Jephcott's approach was at the time.

\section{Early Adoption of Auto/Biographical Methods of Research}


In her book Girls Growing Up (1942) we learn from the foreword it is a 'study of the lives of young working girls. It is told in large part by the girls themselves and there is simplicity and truthfulness in their short autobiographies' Jepchott (1942: 5). The book draws upon of survey data from three hundred British girls to consider their experiences of education (at school and after school), work, leisure, personal relationships and their involvement with girls clubs. Yet this is no 'standard' reporting of questionnaire data as Jephcott combines this material with insights from her own experience of being a youth club organiser in Birmingham and Durham and, perhaps more importantly, autobiographical and biographical insights from the girls themselves. For example, rather than the usual introduction the book begins with One Girl's Story, an autobiographical essay written by one of the girls from the study, Mary Smith. The essay is a richly detailed account of her life in which she provides a narrative of the general arc of her existence from birth onwards, as well as comprehensively documenting and considering the quotidian aspects of her daily life. Typically she writes '...I was just an ordinary girl of thirteen years, my father was out of work as most factory and shipyard members were about this time and my mother was scrimping and saving to keep her family decent' (Jephcott 1942: 13). Mary writes of a 'respectable' working class life in which her family make do as best they can, ricocheting 'along the bottom' just above the poverty line at times, in and out of education and work but seemingly 'happy' and able to manage. Jephcott's approach in this research is 'doing auto/biography', in the contemporary sense (see, for example, Denzin 1989; Plummer 2001). Furthermore, Jephcott's incorporation of auto/biography in her research designs appears well before any of the women's auto/biographies referred to in Plummer (2001), her work is ahead of the established 'origins' of the 'biographical turn' in 1960s and 1970s, as identified by Wengraf et al (2002). Jephcott offers a sociological auto/biographical approach and it is an autobiographical account that still resonates for youth today - issues of youth unemployment and the 'churn' in and out of work, the pressures of family life and relationships, and perhaps more surprisingly for a book of this era, relationships with boys and concerns over body image 'I never bother with the opposite sex and very, very seldom they bother me, but my biggest tragedy is I am fat' (Jephcott 1942: 13). This work transcends dichotomous accounts of past and present and very much 'speaks' to concerns now.

\section{The Use of Images}

Well before the current fashion for visual methods, Strangleman (2008:1492) highlights that there was an earlier sociological tradition of using visual images, while others have 
emphasised the significance of the inclusion of images in the early editions the American Journal of Sociology (see, for example, Becker 1982; Henny 1986; Harper 1988). However, the use of images in that journal had all but disappeared by the 1920s, perhaps because images began to be perceived as 'un-scientific' devices that should be kept separate from 'serious' sociological enquiry (see Hughes 2013). Indeed, it was not until the 'cultural turn' of the 1970s that visual data fully returned to social and cultural analysis (Rose 2007). Yet we would suggest Jephcott was slightly ahead of her time in again recognising the value of images for her books - Homes in High Flats (1967) and Time of One's Own (1971). For example, her study of high-rise living Homes in High Flats is replete with images and the supporting archived material contain numerous folders filled with articles, photographs and maps of high rise living 'from places such as far apart as Melbourne, Philadelphia, Caracas, Prague and Moscow' (Jephcott, 1971:2). The black and white photographs in the book are used to capture the lived realities of high rise living, the changing urban landscape, where children played as well as a concern for documenting local gang culture by photographing graffiti. As she suggests 'when it toured an area its name "Tiny Shamrock" and symbol were written on the wall... The slogan on their own ground showed that this was their territory' (Jephcott 1971: 155). Maps are also a regular feature in this work and it is no surprise that as part of her study of high-rise flats in Glasgow Pearl began by carrying out a mapping exercise illustrating the locations of the new housing developments. These cartographic images were carefully annotated by Jephcott to indicate new housing developments that were complete at the time of her research, each separate tower block depicted by small red squares.

Yet it is perhaps in Time of One's Own (1967) where Jephcott's use of image is key. In this book Jephcott sought to answer the question - 'how do young Scots use their free time nowadays?' (Jephcott 1967: 1) by concentrating on how 15-19 year old Scottish 'ordinary/typical' kids used their spare time. Focused on Drumchapel, Dennistoun and Armadale, Jephcott collected amassed extensive data via variety of interview formats with well over 2,000 young people, from 'casual data' from cafes, pubs, youth groups, dance halls, through numerous informal small discussion groups and the written commentaries and diaries from many others. Yet despite this rich, detailed and varied sources of data the 'stand out' aspect of the book is Jephcott's use of images. Black and white photographs of the neighbourhoods are used to depict public housing and 
residential/industrial landscape of central belt Scotland. However these images are supplemented with something far more innovative, as Jephcott explains:

$[\mathrm{An}] \ldots$ experimental method tried was to get young professional artist to make sketches of how the adolescents in the three areas were spending their hours after work. This technique was used on the assumption that the artist sees much deeper than the man [sic] in the street. (Jephcott 1967: 9)

The book contains twelve distinctive black and white line drawings created by the artists, with an additional thirteen images created but not used in the book. The images offer a detailed representation of teenagers at leisure be it at home, in the dance hall, going to the 'pictures' or more simply 'nowhere to go'. A typical image, although not included in the book, is entitled 'Place of Employment, Dennistoun' in which a young make is depicted hard at work on a drilling machine an surrounded by the accoutrements of his labour ${ }^{[2]}$.

Insert image 1 about here

One enigmatic feature of Jephcott's use of images is that she did not appear to analyse these but rather uses them as images to illustrate 'typicality' of a scene. It may well be the case that the inclusion of such strong black and white line drawings represented something akin to 'ethnographic sketches' with Jephcott not needing to reduce the images to text so as not to 'fix' the meaning of the images for the reader or, as Chaplin (1994: 207) suggests, intrusively punctuate the image 'by verbal discourse'. However, despite the lack of interpretation, for us Jephcott is an innovator in visual methods for three main reasons. First, Jephcott was using images at a time when 'visual sociology' was not that commonplace in the British empirical 'survey oriented' sociology of the 1940s, 1950s and 1960s. Second, it remains to this day very unusual for a researcher to actually commission drawings and paintings of their respondents. While it has become conventional to obtain visual representations produced by the respondents themselves (see, for example Bolton et al 2001) the commissioning of artwork specifically for analytical representation is rare. Finally, Jephcott recognises that the combination of commissioned images, respondent generated images, documentary photography and 'text' collected via interview and observation could make a powerful contribution. Yet Time of 
One's Own does not appear to be cited in any of the standard introductions to visual methods, image-based research of visual sociology.

\section{Full Ethnographic Immersion}

A final aspect of Jephcott's work that we explore here relates to the sheer scale and ambitiousness characteristic of all her projects. Nowhere is this more evident than in her efforts to immerse herself fully in the community of interest whether that was the working lives of women in Bermondsey, the residents of high-rise flats in Birmingham or the inhabitants of Notting Hill in the early 1960s. In each case either she, or the key fieldworkers, lived in the places that were being researched.

A good example of this approach is her study: A Troubled Area: Notes on Notting Hill (1964). For many the area of Notting Hill has become synonymous with urban gentrification, the 'romantic comedy' as well as the internationally renowned annual August carnival. Yet long before the London riots of 2011, or the inner city riots of the early 1980s, this area of North Kensington became synonymous with the race riots of 1958. After the first few months of the study, during which Jephcott immersed herself into the area 'she did not know well', it was decided (given the scale of what she had observed) to focus specifically on the social problems associated with multiple occupancy housing and 'the possibility of stimulating small-scale joint action among the residents on specific problems' (Jephcott 1964: 19). She concentrated on 20 multiple occupancy houses for the detailed study, collecting data through ethnographic observation, collating the written experiences of the residents, photographs and by amassing information on rents, home ownerships and lettings. In doing so Jephcott graphically documents the squalor, the problems of multi-occupancy, the lack of provision for children and adolescents, alongside the lived experiences of 'the residents from overseas' (Jephcott 1964: 80). Ahead of her time Jephcott (1964: 80) pointedly remarks that 'though the unfamiliar colour of their skin causes them to be classed together, they are far from being a group racially or socially' - this at a time when the population of Britain, more broadly, was struggling with 'difference' and where dominant discourses steered towards a homogeneity in the 'them' and 'us'. Indeed, with some foretelling of what was to come in later debates, in their review, Jackson (1965) suggests of the book 'what is quickly made clear is that this is not mainly a problem of race relations but of urban geography, class, bistory, and housing. There are long-term 
explanations which underlie the squalid degeneration of areas like Ladbroke Grove' (Jackson 1965: $350)$.

This style of research has much in common with the traditional community studies such as Stacey's study of Banbury which according to Banton (1961: 237) 'reflects the story of postwar British Sociology - starting with the notion that one should conduct social surveys in the tradition of Booth and Rowntree'. Indeed, it seems likely that given her initial training as an historian Jephcott may well have been influenced by the large-scale poverty surveys of the late Victorian era. Her methods also reflect those used by her American contemporaries studying community through full ethnographic immersion in the field, such as Arnesberg and Kimball (1940) Lynd and Lynd (1929; 1937) and Whyte (1955).

That she was following, to some extent, the traditions of community studies so wellestablished in the US yet writing about the lives of working class women, young people, children and ethnicity in as much depth and with as much thoroughness as she did makes it all the more surprising that her work has been largely forgotten. Pahl (1984:5), writing some twenty years after the publication of Jephcott's works, alludes to the complete absence of the stories of working class women in sociologies of work and community prior to the 1980s. Yet Jephcott had given voice to working class employed women and other neglected groups more than twenty years earlier.

\section{Why is Pearl Jephcott Now Forgotten?}

Give her signification contribution in terms of both quantity and quality and her methodological innovation it is surprising Jephcott's work has been 'forgotten'. Although her work is sometimes cited in later studies of girlhood, leisure time, women and work and high-rise living her absence from the literature is notable. This apparent omission inevitably leads to the question of why Jephcott did not receive due recognition either during her lifetime or subsequently.

Jephcott's career was characterised by her late entry to the formal academic environment, her mobile trajectory (Nottingham, LSE and Glasgow) and her spells working as a freelance researcher. She did not ever secure a permanent academic post yet she published widely, her work was well received and she was well known at the time for her 
expertise, evidenced by her invitations to join government committees and her impressive publication record. This makes it all the more surprising that she never secured a permanent academic post. However, Jephcott's trajectory, like Viola Klein's is testament to the difficulties faced by women in academia during the period she was active as a social researcher. As Delamont (2003:13) has argued, 'male-dominated staff and the prestige of 'male' theory were normal in the period from 1960 to 1980'. Without connections to the academic world Pearl, much like Viola Klein, another female sociologist of the period, was for the majority of her career,

'a solitary and self-employed worker without a male academic partner or patron to help sustain entry in to academic life and ... without permanent academic employment leaving her in constant search of means of support' (Lyon, 2007: 830).

Similarly, Olive Banks, another female sociologist some twenty-three years Pearl's junior, also struggled to secure a job in academia despite having a $\mathrm{PhD}$ and considerable recognition for her published work. Purvis (2008:365), writing about Banks, describes her struggles as being down to the 'considerable prejudice against women entering the male-dominated academic profession'. Indeed, 'Neither the topic of women, nor the existence of women as sociologists were apparent in 1968. There were some women lecturers, and a tiny number of women professors, but they were not visible in the subject' (Delamont 2003: 16).

That Jephcott's career was so precarious and temporary in nature is then not surprising given the social norms of the period. Her experience mirrors that of other female social scientists who were rarely able to secure permanent academic positions and had to rely extensively on the patronage of more senior male academics. For example, the project which resulted in the publication of Married Women Working was carried out under the 'leadership' of Titmuss, although Pearl was the main researcher. Her study of young people's leisure time 'Time of One's Own'was led by her and the book was published in her name, however, the opening pages of the book list Professor Donald Roberston, a senior academic at Glasgow in brackets after Pearl's name. The reason for this is unclear but we suspect that the grant money awarded for the study was possibly awarded to the more senior Robertson. 
It seems that Pearl was employed in each case to take on the role of lead researcher on grant applications that had been made by and awarded to men in senior academic roles. The nature of these positions was that they were short term, lasting only for the duration of the research grant and no job security was offered. It was also difficult to secure permanent academic positions through routes now considered standard. Recruitment practices were seemingly unregulated in any way during the post-war decades. Platt (2000, 2004) has explored the differences between women's and men's careers in British Sociology since the early post-war period and has illustrated how recruitment practices were informal and often facilitated by word of mouth recommendations. Our own explorations of the Norbert Elias archive are testament to such informal, and often sexist, practices. There were relatively few jobs at the time and young, male graduates recommended by their male seniors often filled those that did exist. The following extract from such a letter illustrates the difficulties faced by women:

We have appointed [....] to an assistant lectureship... and, finally, a girl - imagine!!! - of 27 who took PPE in Oxford, who very fortunately has had quite a bit of social statistics and also taught...People in the department were impressed by her, though I myself was not sure whether to appoint her or a girl from [...]. A complication there, however, is that she is married and has two children who would have come over with her.... (Ilya Neustadt, $12^{\text {th }}$ June 1963)

As Platt $(2000,2004)$ highlights, in the past it was not always necessary to hold a higher degree in order to secure an academic post. Pearl would therefore certainly not have been precluded from posts due to a lack of academic qualification as she held an MA. It seems more likely that her gender, her trajectory of temporary research contracts, her lack of an institutional home, her interest and focus on unfashionable topics with a firmly empirical basis and her lack of male patronage led to her disappearance from the sociological canon.

\section{Conclusions}

We have offered here an appreciation of the work of Pearl Jephcott and in doing so have argued that her legacy is such that she deserves far greater recognition. Her contribution to sociology, in particular in the areas of girlhood, women, work, motherhood, leisure time, young people and housing to name but a few, is evidence enough that she was a prolific social scientist of her era. Not only was she enormously productive carrying out 
research on a large scale she was also innovative, adventurous and ambitious in her methodological approaches. She was 'playing' with methods at a time of great sociology dogma, of British survey 'practicality', or sociology in the US that was still dominated by grand theory or abstracted empiricism. Yet, despite these dominant trends, Jephcott positioned her research - as her use of images reveals - to capture the quotidian, she offered sociology of the mundane. She did not, as Hughes (2013) would suggest, equate sociological importance with social importance in her studies. What Lyon (2007) has written about Viola Klein, could equally have been applied to Pearl Jephcott.

... as an academic woman in search of a voice and a career in a male-dominated profession and as an empirical researcher at a time when theorizing was at a premium in sociology - her life and intellectual contribution was marked by great creativity, and by frequent contributions to public debates about the changing roles of women. (Lyon 2007: 829)

Combine her writings on youth, leisure, housing, delinquency, childcare, sociological method, and so forth, with the work she did to capture and explore the changing roles of women and then, and only then, does one has a full reflection of Jepchott's legacy for British sociology. Her work was ground breaking in many respects yet despite this legacy she is largely forgotten - so why is her legacy important? Her legacy is important because the themes she dealt with are so contemporary, current and relevant and the manner in which she explore them so innovative. Jephcott deserves to be reconsidered and reappraised. 


\section{Acknowledgements}

We would especially like to thank Moira Rankin, Kiara King and other colleagues at the University of Glasgow Archives for their on-going support of this research and for cofunding, with the authors, the digitisation of the images from Jephcott's Time of One's Own. We would also like to thank Tina Stiff and Bharat Mehta and of the Trust for London, Katherine Webb of the York University, Kevin Roberts from the Birmingham Archives and Heritage Service, Upasana Young of UNICEF and Eddie Barry of the

Bellahosuton Bequest Fund. We are very grateful to the anonymous reviewers, and to Jason Hughes, for their comments.

\section{Funding}

We acknowledge the support of the University of Leicester College of Social Science Research Committee for the award of a research development grant to support our work on Pearl Jephcott.

\section{Notes}

[1] Also see Smith (2008) and Turnbull (2000, 2002 and 2004)

[2] Permission to reproduce the Image 1 had been granted by the University of Glasgow Archival Service who are the custodians of the images relating to Time of Ones Own. This image is archived in file DC127/23/22.

\section{References}

Arnesberg, C.M. and Kimball, S.T. (1940) Family and Community in Ireland. Harvard: Harvard University Press.

Aronowitz, S. (2012) Taking it Big: C Wright Mills and the Making of Political Intellectuals. New York: Columbia University Press.

Banton, M. (1964) Anthropological Perspectives in Sociology, British Journal of Sociology, 15(2): 95-112.

Banton, M. (1961) Review of Stacey, M. (1960) Tradition and Change: a Study of Banbury. The ANNALS of the American Academy of Political and Social Science 335, p.237

Bell, C. and Newby, H. (1977) Doing Sociological Research. London: George Allen and Unwin. 
Chriss, J. (2001) Alvin W. Gouldner and Industrial Sociology at Columbia University, Journal of the History of the Behavioral Sciences, Vol. 37(3), 241-259.

Delamont, S. (2003) Feminist Sociology. London: Sage

Denzin, N. (1989) Interpretative Biography. California: Sage.

DeVault, M.L. (2007) Knowledge from the Field, Chapter 5 in Calhoun, C. (ed.) (2007) Sociology in America: A History. Chicago: University of Chicago Press.

Elias, N. (2009) On Sociology and the Humanities: Essays III. Vol. 16 The Collected Works of Norbert Elias. Dublin: University College Dublin Press.

Gerhardt, U. (2002) Talcott Parsons: An Intellectual Biography. Cambridge: Cambridge University Press.

Goodwin, J. and Hughes, J. (2011) Ilya Neustadt, Norbert Elias, and the Leicester Department: Personal Correspondence and the History of Sociology in Britain, British Journal of Sociology, Volume 26, No. 4. pp. 677-695.

Goodwin, J. and O'Connor, H. (2013) Ordinary Lives: 'Typical Stories' of Girls' Transitions in the 1960s and the 1980s, Sociological Research Online, 18 (1) 4 <http://www.socresonline.org.uk/18/1/4.html> 10.5153/sro.2881

Goodwin, J. and O'Connor, H. (2006) Norbert Elias and the Lost Young Worker Project, Journal of Youth Studies, Vol. 9, No. 2, pp. 159-173.

Halsey, A.H. (2004) A History of Sociology in Britain, Oxford: Oxford University Press.

Harper, D. (1988) Visual Sociology: Expanding Sociological Vision, American Sociologist, 19(1): 54-70.

Henny, L.M. (1986) Trend Report: Theory and Practice of Visual Sociology, Current Sociology, 34(4): 1-76.

Horowitz, I. L. (1983) C. Wright Mills: An American Utopian. New York: The Free Press.

Hughes, J. (2013) Norbert Elias and the Habits of Good Sociology, Human Figurations, 2(1). [http://hdl.handle.net/2027/spo.11217607.0002.107.

Hughes, J. (2012) Editor's Introduction: SAGE Visual Methods, in Hughes, J. (ed) (2012) Visual Methods, Volume I. London: Sage.

Jephcott, P. (1967) Time of One's Own: Leisure and Young People. Edinburgh: Oliver \& Boyd.

Jephcott, P. with Robinson, H. (1971) Homes in High Flats. Some of the human problems involved in multi-storey housing. Edinburgh: Oliver and Boyd.

Jephcott, P. (1964) A Troubled Area. Notes on Notting Hill. London: Faber and Faber.

Jephcott, P. (1963) Unpublished Letter to Charles Furth, George Allen \& Unwin LTD, $23^{\text {rd }}$ May 1963. The Archive of British Publishing and Printing - Records of George Allen \& Unwin Ltd. Reading: The University of Reading 
Jephcott, P., Seear, N. and Smith, J.H. (1962) Married Women Working. London: Routledge and Kegan Paul.

Jephcott, P. (1954) Some Young People. London: George Allen and Unwin.

Jephcott, P. (1948) Rising Twenty. Notes on ordinary girls. London: Faber and Faber

Jephcott, P. (1943) Clubs for Girls. Notes for new helpers at clubs. London: Faber and Faber.

Jephcott, P. (1942) Girls Growing Up. London: Faber and Faber

Johnston, B. V. (1995) Pitrim A. Sorokin: An Intellectual Biography, Kansa: University Press of Kansas.

Lybeck, E.R. (2013) Lester Ward and Patrick Geddes in early American and British sociology, History of the Human Sciences, 26 (2): 51-69.

Lynd, R.S. and Lynd, H.M. (1937) Middletown in Transition, New York: Harcourt Brace.

Lyon, E.S. (2007) Viola Klein: Forgotten Émigré Intellectual, Public Sociologist and Advocate of Women, Sociology, 41(5): 829-842.

Neustadt, I. (1962) Unpublished Letter to Norbert Elias, 12 ${ }^{\text {th }}$ June 1963. Marbach: Deutsches Literaturarchiv

Nind, M., Wiles, R., Bengry-Howell, A. and Crow, G. (2013) Methodological Innovation and Research Ethics: Forces in Tension or Forces in Harmony, Qualitative Research 13(6): 650-667.

Oakley, A. (2011) A Critical Woman: Barbara Wootton, Social Science and Public Policy in the Twentieth Century. London: Bloomsbury.

Oakley, A. (1989) Women's Studies in British Sociology: To End at Our Beginning? The British Journal of Sociology, 40(3): 442-470.

Oakley, A. (1974) The Sociology of Housework. London: Martin Robinson.

O'Connor, H. and Goodwin, J. (2012) Revisiting Norbert Elias's Sociology of Community: Learning from the Leicester Restudies, The Sociological Review, Vol. 60, No.3, pp. 476-497.

Pahl, R.E. (1984) Divisions of Labour, London: Blackwell.

Platt, J. (2007) The Women's Movement and British Journal Articles, 1950-2004. Sociology, 41(5): 961-975.

Platt, J. (2004) Women's and Men's Careers in British Sociology. The British Journal of Sociology, 55(2): 197-210.

Platt, J. (2003) The British Sociological Association: A Sociological History, Durham: Sociology Press.

Platt, J. (2000) Women in the British sociological labour market 1960 - 1995. Sociological Research Online, 4 (4). p. 23. 
Plummer, K. (2001) Documents of Life 2. London: SAGE.

Purvis, J. (2008) Olive Banks (1923-2006): an appreciation. British Journal of the Sociology of Education, 29 (4) 363-368.

Roberts, H. and Woodward, D. (1981) Changing Patterns of Women's Employment in Sociology: 1950-80. The British Journal of Sociology, 32(4): 531-546.

Roberts, H. (1981). 'Some of the boys won't play any more': the impact of feminism on sociology', in Spender, D. (ed.) Men's Studies Modified: the impact of feminism on the academic disciplines. Oxford: Pergamon.

Rose, G. (2007) Visual Methodologies: An Introduction to the Interpretation of Visual Materials, London: Sage

Savage, M. (2008) Elizabeth Bott and the formation of modern British sociology, The Sociological Review, 56(4): 579-605.

Smith J. H. (1961) Managers and Married Women Workers, The British Journal of Sociology, 12(1): pp. 12-22.

Smith, M. K. (2008) Pearl Jephcott, youth and the lives of ordinary people. The Encyclopedia of Informal Education, www.infed.org/thinkers/pearl_jephcott.htm].

Stacey, M. (1960) Tradition and Change: A Study of Banbury. London: OUP.

Strangleman, T. (2008) Representations of Labour: Visual Sociology and Work, Sociology Compass, 2(5) 1491-1505.

Stanley, L., Dampier, H. and Salter, A. (2010) Olive Schreiner globalising social inquiry: a feminist analytics of globalization, Sociological Review 58(4): 656-79.

Turnbull, A (2004) Jephcott, (Agnes) Pearl (1900-1980) in Oxford Dictionary of National Biography. Oxford: Oxford University Press, 2004 http://www.oxforddnb.com/view/article/67334, accessed 27 June 2011.

Turnbull, A. (2000) Giving girls a voice: Pearl Jephcott's work for young people Youth and Policy 66: 88-100.

Turnbull, A. (2002) Classic texts revisited: Clubs for Girls. Youth and Policy 73: 66-74.

Wengraf, T. Chamerlayne, P., and Bornat, J. (2002) A Biographical Turn in the Social Sciences? A British-European View, Cultural Studies $<=>$ Critical Methodologies, 2(2): 245268.

Whyte, W.F. (1955) Street Corner Society, Chicago: Chicago University Press.

Wiles, R., Crow, G. and Pain, H. (2011) Innovation in Qualitative Research Methods: A Narrative Review, Qualitative Research 11(5): 587-604. 
John Goodwin is a Professor of Sociology at the University of Leicester. His principal research interests include the sociology of work, (especially education to work transitions and gender and work), social science research methods (life histories, work narratives, auto/biography, the re-use of qualitative and archival data) and the history of sociology.

Henrietta O'Connor is a Reader at the University of Leicester. Her main research interests focus on youth transitions from school to work, work and community and qualitative research methods, in particular the secondary analysis of qualitative data and the use of online research methods.

\section{IMAGE FOR INCLUSION}

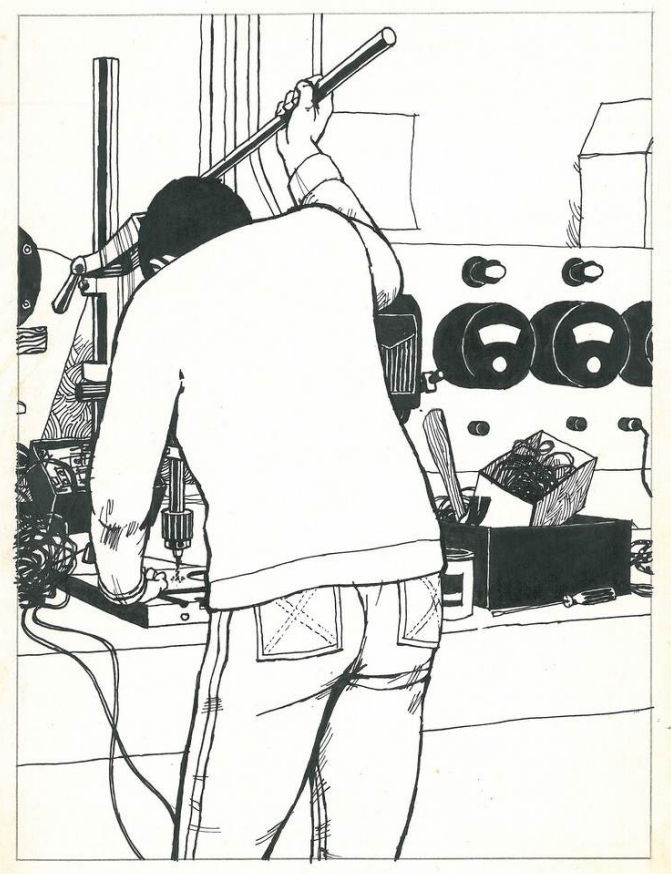

